\title{
Multimodality, mass migration and English language teaching ${ }^{1}$
}

\section{Multimodalidade, migração em massa e ensino de língua inglesa}

Vanderlei J. Zacchi*

Universidade Federal de Sergipe

Aracaju, Sergipe / Brasil

\begin{abstract}
This paper aims to discuss the use of multimodality in English language teaching. The corpus consists of a set of activities based on a series of pictures related to the seizure of two trucks carrying US-bound migrants in 2011. Two different groups, comprised of pre-service and in-service English language teachers, took part in the research. The first part of the activity involved loose interpretations of the pictures and a discussion about migration nowadays. Afterwards, other activities were carried out based on Luke and Freebody's four-resources model (1990). Some preliminary analyses lead us to conclude that the reading of images is very much culturally sensitive and that multimodal ways of meaning making are becoming more powerful in the globalized, digital era, turning them into an important means for English teaching nowadays.
\end{abstract}

KEYWORDS: multimodality; ELT; migration; the four-resources model

RESUMO: O objetivo deste trabalho é discutir o uso da multimodalidade no ensino de inglês. $\mathrm{O}$ corpus da pesquisa se constitui de atividades baseadas numa série de imagens relacionadas à apreensão de dois caminhões carregando imigrantes para os Estados Unidos em 2011. Participaram da pesquisa dois diferentes grupos com professores em formação inicial e continuada. A primeira parte da atividade incluiu interpretações livres das imagens e uma discussão sobre migração na atualidade. Posteriormente, foram realizadas outras atividades com base no four resources model de Luke e Freebody (1990). Análises preliminares mostram que a leitura de imagens é muito mais sensível ao contexto e que a construção de senti-

\footnotetext{
* vanderleiz@yahoo.com

${ }^{1}$ A previous version of this paper was presented at the Western States Rhetoric and Literacy Conference in Winnipeg, Canada, on 19 October 2012. The research for this article was made possible, in part, through support provided by CNPq (process \# 401394/2010-7). I thank Dr. Simone Batista da Silva of Universidade Federal Rural do Rio de Janeiro for her comments on an earlier version of this paper. I would also like to thank the anonymous reviewers of the first manuscript for their helpful comments.
} 
dos por meio da multimodalidade torna-se mais poderosa com a globalização e a digitalidade, o que faz dela um importante meio para o ensino de inglês atualmente.

PALAVRAS-CHAVE: multimodalidade; ensino de língua inglesa; migração; four resources model

Here, in the visual, the lesson of reading is the toughest. There are no guarantees at all.

SPIVAK (2012, p. 507)

\section{Introduction}

This paper aims to discuss the use of multimodality in English language teaching and English language teacher education in Brazil, taking mass migration as a point of departure. Nowadays, meaning is made in ways that are increasingly multimodal, so that written linguistic modes of meaning are becoming more and more intertwined with visual, audio, spatial and gestural patterns of meaning (THE NEW LONDON GROUP, 2000). The focus of this paper will primarily be on the intersection between the visual and the verbal modes. The corpus is comprised of activities developed with two different groups at different times: a group of pre-service English Language teachers and a group of in-service English language teachers in Sergipe, Brazil. In the first case, the activity was developed by myself with students from an undergraduate course in Letters at a federal public university. In the second case, the activity was part of a project which sought to research in-service English language teacher education in Sergipe, as well. This project was conducted by a research team that involved professors, myself included, and students from an undergraduate English course in Letters at a federal public university.

The activity was based on a series of pictures related to the seizure, by Mexican police, of two trucks carrying US-bound migrants in 2011. The first part of the activity consisted of interpreting the pictures without the captions and the headline. After that, the headline and the subject were presented to the participants, and other activities were carried out based on Luke and Freebody's four resources model (1990), in an attempt to cover other aspects of the subject through an analysis of the coding, text-meaning, pragmatic and critical practices.

The discussions proved to be quite fruitful and involved several aspects, especially related to (illegal) migration. Both groups were asked 
to compare the situation of the Mexicans to that of other people in Brazil and in their region. Several accounts were made about relatives who had migrated to other parts of the country looking for better living conditions, since the region where these people live has historically faced severe natural and economic conditions. ${ }^{2}$ It is important to notice, however, that there are considerable differences between transnational mass migration and intranational migration within Brazil. Although the cause may be similar in both cases (economic conditions), migration in Brazil has consistently taken place for centuries and not as a response to specific, transitory events. Nor is it deemed to be illegal. Even so, in both cases, migration is a thorny, relevant issue with both local and global reach. Consequently, it provides good material to be dealt with meaningfully in the English language classroom.

Some preliminary analyses lead us to conclude that the reading of images is more culturally sensitive and presents more possibilities of interpretation when it is not limited by a written-linguistic mode of meaning. When the participants described the images, they tended to bring to their reading the context where they themselves are situated. After they had learned the context of the images through the verbal mode, their interpretation changed. Obviously, these interpretations were still subjective, but in a different way. This comes to show that multimodal ways of meaning making are becoming more powerful in the globalized, digital era, where the written-linguistic mode can no longer be seen as an independent all-powerful mode. This change deeply impacts language teaching in the contemporary world.

The first part of this paper is dedicated to a discussion of multimodality and its ubiquity in today's world, followed by a brief presentation of the four-resources model of reading, as proposed by Luke and Freebody (1999).

\footnotetext{
${ }^{2}$ There were also accounts of foreign people coming to live in Sergipe, mainly due to economic restraints. It is important to note that mass migration - especially involving Europe and the Middle East - was not as sensitive an issue at the time this research was conducted as it is today. Nevertheless, it has been an important topic for over a century in many parts of the world. Illegal migration in the US-Mexico border region has been prominent in recent decades, as has internal migration within Brazil, a tendency that has shifted considerably in the last few years, as I will discuss below.
} 
Afterwards, I will contextualize the research and the activities that were developed with both groups of participants. Finally, I will analyze some of the data that were collected during the research process.

\section{Theoretical background}

\subsection{Multimodality}

Multimodality has come to play a major role in education as of late. Its relevance comes partly from a ubiquitous, in and out-of-school, combination of different modes for making meaning with texts nowadays. One important aspect of this approach is that there is no centrality as regards each of the different modes that compose a text. Their combination also produces a different meaning when compared to all the previous meanings implied individually in the different modes.

An earlier version of what would come to be known as multimodality may have come from the Brazilian educator Paulo Freire. In his Pedagogia do oprimido (2005), first published in the 1960's, he presents a series of "channels" to "codify" (p. 135) a text. According to him, such a codification can be either simple or compound. In the first case, it can be visual, tactile or auditory. In the second case, a "multiplicity of channels" can be used.

For The New London Group (2000, p. 28), the five modes of meaning making that are gaining special relevance - other than the traditional linguistic one - are: visual, audio, spatial, gestural and multimodal. Multimodality refers to a text composed of two or more modes. It also presupposes that the different modes in a text do not function alone, but rather in an integral way, so that the multimodal dimension adds different features not yet available in any of the specific individual modes present in a text.

It is hard to imagine a text that is not multimodal nowadays. One can think of a still image, or a piece of music, but most texts available in our daily activities are multimodal: songs, videos, video games, newspaper articles, among many others. Whereas this is not a totally new phenomenon, it has been gaining increasing attention in the classroom. Even so, the use of multimodal texts in teaching should not be seen as an end in itself. One of the aims of this paper is to show alternative approaches to them. There is a long tradition in the English classroom of dealing with songs and images, for example, simply as a support for the teaching of grammar, vocabulary 
and other structural aspects. Multimodality breaks with such hierarchy and provides opportunities for a more integral approach to teaching.

It is also important to take into account the role of new media for the growing importance of multimodality. The ease with which we can produce and circulate multimodal texts within virtual spaces has changed the way in which we communicate. Even a newspaper article, which would be composed of only still images and written texts in print, can now also comprise a video (with an interview, for example) or other audio or moving image texts. Video clips are another good example. They became popular on TV in the 1980's, but back then the viewer had little power to interfere in the production process. Today, people can produce, upload, watch and comment on video clips via YouTube and other platforms. This feature has not only given increased power to the user, but has also made multimodal texts more common and more available. The result is that the way in which people make meaning out of texts is also changing drastically.

The importance of multimodal texts in instructional environments is well illustrated by Dimitriadou, Tamtelen and Tsakou (2011, p. 225) when they state that these texts "exceed the traditional 'chalk and talk teaching', which is usually dominated by sterile, shallow, superficial and controlling practices." As a result, they can support teachers to avoid "the informational character and stereotypical formalism of teaching." It is certainly true that they can really help teachers to accomplish this. However, it would be reasonable to add that the use of multimodal texts in the classroom is not enough to change a teaching reality if teachers are unwilling and unprepared to do so.

It is not difficult to notice that the visual is the most pervasive mode of meaning making of all the above mentioned references. Texts containing images have become a commonality. This tendency points to a situation where reading and interpreting texts are taking on a new dimension. It is important, therefore, to take this into account in the language classroom. Reading visual texts, much like any other type of text, cannot be taken for granted, as if they had no ideological dimension and were not inscribed in power. Therefore, bringing them to the classroom is crucial in an era dominated by these new media and by new ways of communicating and interacting. For Kress (2000, p. 183), technologies of information lend themselves to "visualisation." Furthermore, economic changes in the postindustrial era are to a certain degree "information-driven" or "knowledge- 
based." Bearing that in mind, Kress further believes that "information of various kinds may be more aptly expressed in the visual rather than in the verbal mode."

It is not my intention to celebrate the new media and the Internet as revolutionary per se, falling into the trap of a technological determinism (SNYDER, 2008). But we cannot simply ignore the place that they occupy in contemporary societies. As already mentioned, they are inscribed in power, and such an aspect cannot be overlooked. One of the main reasons for developing the activities discussed in this paper was to present multimodality and visual texts as sites of struggle, so that readers (in this case, teachers, students, and teachers-to-be) would not look at images as just neutral, unbiased texts, merely functioning as an ornament to written texts. Moreover, as proposed by Silva (2014, p. 163), developing critical multimodal literacy with teachers may lead to the construction of a "hybrid identity", influencing their students to also construct "a plural identity for the multimodal communicative interactions in which they take part."

According to Barthes (1977, p. 39), every image is polysemous and implies "a 'floating chain' of signifieds", giving the reader the possibility of choosing some and ignoring others. However, such polysemy implies some degree of dysfunction, since it poses a question of meaning. Therefore, every society develops techniques to "fix the floating chain of signifieds" (italics in the original) in order to combat "the terror of uncertain signs": the "linguistic message" is one of these. Consequently, according to him, the linguistic text has a repressive mood and reveals the ideology and the degree of morality that inform a society. For Kress (2003, p. 4), the meaning making capacity of images lies in the fact that they are already "filled with meaning. There is no vagueness, no emptiness here. That which is meant to be represented is represented. Images are plain full with meaning, whereas words wait to be filled." Based on that, Morgan (2009, p. 310) states that "We are more likely to activate prior knowledge and generate new meanings if we 'read' a photograph, for example, as opposed to when we read a newspaper article in a foreign language with which we are unfamiliar." As we will see below, the participants in this research had more choices of interpretation when faced only with an image, i.e. without a written text.

However, two aspects are worth mentioning at this stage. First of all, a text is a text, whatever the modes that may be at play, which implies the use of language as a means of representation. Therefore, some degree of interpretation is required, which makes representation subjective and 
not an objective substitute for "the real thing." In other words, whatever the mode used in a text presupposes subjective interpretation to a greater or lesser degree. What I am trying to show in this paper is that visual texts, in the contexts in which they were used, have more potential to generate new meanings (MORGAN, 2009, p. 310) than plain written ones. Second, the different components of a text are independent but not autonomous, so that an image is connected to a written text but not dependent upon it and vice-versa (KRESS; VAN LEEUWEN, 2006; ZACCHI, 2009). In fact, according to Monte Mor (2006, p. 133), multimodality intertwines and brings together different modes of communication, resulting in a different effect not yet available in any of the specific individual modes present in a text.

Ultimately, what I sought to promote was some degree of literacy that involved reading/interpreting visual and multimodal texts (a visual/ multimodal literacy) in the same way that readers do with written texts, considering the fact that studying/teaching a foreign language does not exclude the exploration of non-verbal texts. Therefore, the activities under discussion here followed two steps: an interpretation of the images (the visual mode) and a discussion of the multimodal text resulting from the combination of images and a headline. As we shall see in the analysis below, there was considerable change in interpretation from one step to the other.

\subsection{The four resources model}

The four resources model of reading was developed by Allan Luke and Peter Freebody in 1990 (LUKE; FREEBODY, 1999; TEMPLE, 2005). The four roles ${ }^{3}$ for the reader - "necessary but not sufficient", according to the authors (LUKE; FREEBODY, 1999) - were devised with a postmodern, text-based culture in mind. The idea was to encourage different levels of critical literacy. The authors were very much influenced by several critical literacy movements, going back to the Brazilian educator Paulo Freire (2005).

Luke and Freebody (1999) recognize that the model is a normative one and therefore requires continual critique and reformulation in light of new social and cultural contexts for literacy practice. It is normative

\footnotetext{
${ }^{3}$ In a later revision of the model, Luke and Freebody (1999) substituted the term "roles" for "practices". Whereas the former suggests something previously defined for someone to "fit into", individualizing the process, the latter describes "substantive and visible, dynamic and fluid practices undertaken by human agents in social contexts."
} 
as opposed to descriptive, since the aim is less to describe how things are than to make moral, political, social and cultural choices about how they should be. Therefore, it is closely related with the literacy process, which, according to the authors, "involves shaping and mastering the repertoire of capabilities called into play when managing texts in ways appropriate to various contexts." Since literacy is a social practice, it is highly dependent on the various contexts in which it is set. Thus, rather than simply being "scientific", or seeking skills acquisition and knowledge transmission, teaching literacy is about "the kind of literate society and literate citizens or subjects that could and should be constructed."

These principles are embedded in the "normative" model devised by Luke and Freebody, which revolves around four types of practices, as shown below.

- Coding practices

According to Luke and Freebody (1999) the aim of this resource is to "break the code of written texts by recognizing and using fundamental features and architecture." The idea is to "decode" texts to see how they work and how they are structured. It also implies that the text has a grammar (TEMPLE, 2005), not as a system composed of a set of rules, but as the different parts that make up a certain type of text.

- Text meaning practices

This resource explores the relation between a "text's interior meaning systems" (LUKE; FREEBODY, 1999) and the reader's available knowledge and experience of other cultural texts and meaning systems. If coding practices focus on the structure of the text, the text meaning practices allow for situated interpretation, as the reader puts his/her previous experience and knowledge in dialogue with those in the text.

- Pragmatic practices

According to Luke and Freebody (apud TEMPLE, 2005, p. 18), this resource focuses on pragmatic practices by exploring the following questions: "What do I do with this text, here and now? What will others do with it? What are my options and alternatives?" For the authors (LUKE; FREEBODY, 1999), the purpose of this resource is "knowing about and acting on the different cultural and social functions that various texts perform inside and outside school." Similar to coding practices, pragmatic practices presuppose the existence of a set of features that make up a certain type of text or genre, but they also take into account the social and cultural contexts where this text circulates. 
- Critical practices

The aim of this type of practice is to allow learners to "critically analyze and transform texts by acting on knowledge that texts are not ideologically natural or neutral - that they represent particular points of views while silencing others and influence people's ideas - and that their designs and discourses can be critiqued and redesigned in novel and hybrid ways" (LUKE; FREEBODY, 1999). Whereas pragmatic practices explore questions like, "What do I do with this text?", critical practices may elicit questions like, "What is this text trying to do to me?" (LUKE; FREEBODY apud TEMPLE, 2005, p. 18).

\section{The research contexts}

As mentioned above, the data presented here were taken from two sources. One was an activity developed by myself in an intermediate English conversation class as part of an undergraduate course in Letters at a federal public university during two classes between August 26 and 28, 2011. The classroom consisted of about thirty students - or pre-service teachers, since they were in a teacher education course. The data presented here come from notes taken during and after the development of the activity in the classroom.

The second source of data comes from an academic project funded by CNPq, which was conducted from 2010 to 2012 and sought to research in-service English language teacher education in Sergipe. The study involved professors and students from an undergraduate English course in Letters of a public federal university. The participants were thirteen English language teachers from public schools in Sergipe. The data were mainly collected through interviews, but also involved questionnaires, class observation and field diaries. Meetings were held between researchers and participants on a regular basis for over one year. The aim was to discuss issues related to English teaching and literacies, and to develop activities for the classroom based on those discussions. Located in the Northeastern region of the country, Sergipe is Brazil's smallest state. The Northeast is a region historically characterized by social and economic inequalities. For that reason, and because of long lasting periods of severe drought, a large number of people used to migrate to other, wealthier regions of the country, especially the Southeast. In recent years, that tendency has shifted due to sustained initiatives from the federal government to tackle inequalities. 
The starting point of the investigation, in both scenarios, was a series of three photo images taken from the Internet:

(a)

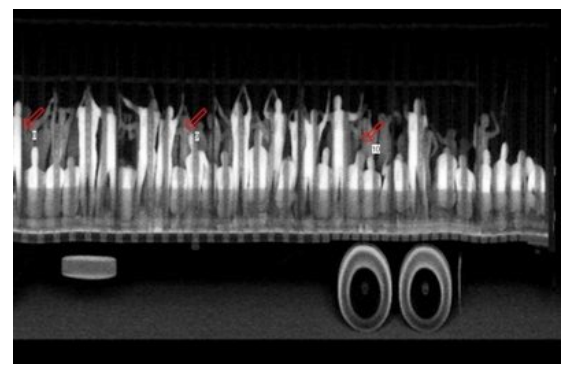

(b)

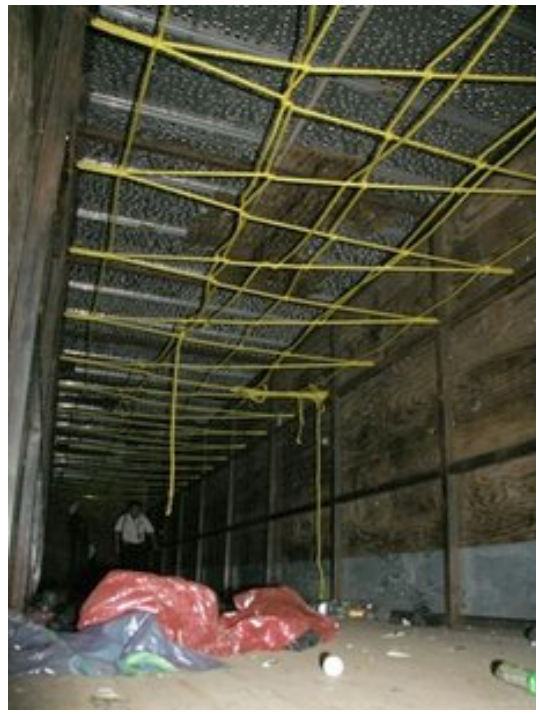

(c)

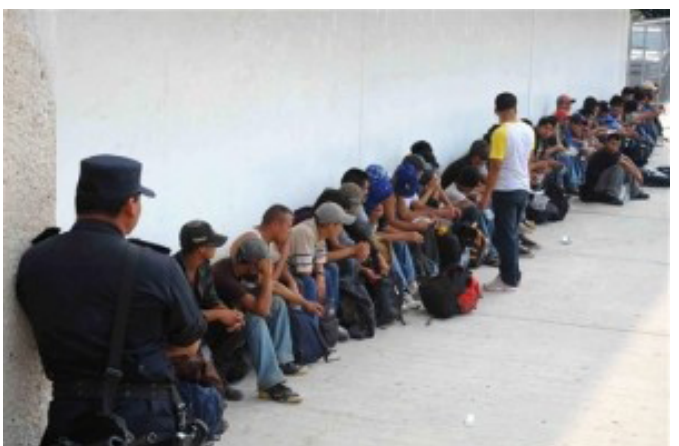


The three images were selected from a range of pictures available at the Yahoo! News website (http://news.yahoo.com) on May 14, 2011. They depict the seizure, by Mexican police, of two trucks filled with illegal migrants bound for the United States. The pictures were presented to the participants in the chronological order of the real events. The first one (a) is an $\mathrm{x}$-ray image of one of the trucks with the migrants inside. The second one (b) shows an empty truck, after it was seized by the police. And the last one (c) shows some of the migrants outside the trucks, probably waiting for some legal decision about their fate.

The activity was divided into two main steps. In the first one, the participants had access to the pictures outside their factual context. The participants were asked to look at the images and interpret them at will. No contextualization was provided, so as not to influence their readings.

The second step began with the presentation of the headline:

"Mexico police find 513 US-bound migrants in trucks"

As we can see, it is not easy to link the images to the events without the aid of the linguistic mode, even if we take into account the fact that news headlines are usually highly interpretive and biased, while pretending to be descriptive and objective. This pretentious objectivity is also present in images, which was also a feature under analysis, as I will present later.

In both steps, the participants (in groups or individually) were requested to present their interpretations of the pictures. ${ }^{4}$ The purposes of this two-stage activity were:

- To assess how English language teachers and students interpret images;

- To check how cultural assumptions influence their interpretations;

- To see how interpretations change from one meaning-making mode to another;

\footnotetext{
${ }^{4}$ The second part of the activity was not fully performed with the in-service teachers. However, in a group meeting, after all the interviews had already been done, I did present the material to them and gave an account of how I had explored it in classroom with the pre-service teachers. I will comment on the results of this meeting below. In addition, the classroom activities with the undergraduate students occurred while the interviews with the in-service teachers were being conducted. Since the process with the latter was considerably longer, by the time we held this group meeting I had already concluded the activities with the students.
} 
- To explore ways to critically deal with visual and multimodal texts in the classroom;

- To discuss mass migration as a global and local issue.

When I selected the photo images for this activity I took into account the potential for loose interpretations, especially for picture (a) and without the headline. Following from the real event, they were displaced in chronological order and they make up a narrative. As already mentioned, picture (a) shows an x-ray of one of the trucks. After I had done the first interview with one of the in-service teachers, I sent the following e-mail to the members of the research team:

I asked [one of the teachers] to talk about the images without reading the headline. Only after that did I show it the headline to her. During our conversation, some ideas occurred to me. The first picture (x-ray of the truck), for instance, could be explored for its aesthetic potential. But maybe all of them. There are patterns and shapes that are recurring. So the first picture could be seen as a bar code and there is a kind of homogenization in general (of shapes) that reveal a kind of desubjectivization, intensified by the theme of hordes of migrants, that is, there are no faces, just numbers. Besides, $\mathrm{i}$ It is also possible to explore issues such as migration, mobility, unemployment, boundaries; issues that are intensified by globalization but with local outcomes. (Personal e-mail, May 24, 2011)

So in my initial, personal interpretation, I could see some kind of objectivization of the people involved, the type of presumed neutrality and objectivity usually assumed by media corporations. It is interesting to note, in this case, that the pictures are credited to different copyright owners in different websites (Reuters, AP, EPA).

Moreover, the idea of selecting these pictures came about when I was thinking of an activity to be developed during the interviews with the inservice teachers. Instead of asking the teachers direct questions about how to teach English, the idea was to have them reflect about it through images. Hence, the selected images fit in well with the purpose, since they both allowed for an extended work with multimodality and provided a relevant, situated and up-to-date subject to discuss: mass migration. Later, and for the same reasons, I decided to use the same images in a classroom activity with pre-service English teachers. 


\section{Making meaning}

In this section, I will analyze some of the data that were collected during research with both groups of participants.

\subsection{Pre-service teachers}

As mentioned above, the data presented here are the result of an activity developed by myself in an intermediate English conversation class of a course in Letters at a federal public university. This group consisted of about thirty students.

I had the students set up small groups and attribute meanings to the pictures. No contextualization was given, and the students were prompted to interpret them at will. The initial questions were: "What do you see in these pictures?" "Do you see any relation between them?" One of the reasons why I chose these pictures, as I mentioned earlier, was their "aesthetic" potential, so that the participants could build different and alternative narratives, without many connections to real events. What I expected, in fact, was a more connotative account of it. However, what I noticed was that people usually tend to find the "correct" reading of a text, and linking it to real events is one way to do that, even if mediated by a news website.

In this first step, a general comment about picture (b), which showed the inside of one of the trucks after the seizure, was that it resembled a dirty, abandoned warehouse. As for picture (c), it raised a general view that it represented a situation displaying order and discipline, maybe some people queuing for a job. From all three pictures, however, the first one generated the most discussion and drew the most interesting comments, maybe because it is more abstract and does not show so much realism as compared to the other two. Thus, the students presented the following interpretations:

- religious people in a play in white clothes (wearing tunics)

- a presentation in a theatre (ghosts with wooden legs or a choir)

- an x-ray of a truck full of people (maybe refugees); or "pau de arara"

- a play: actors performing; Jesus crucified; the last supper

- a ship/truck: people dancing and celebrating to axé music

- a birthday cake with lit up candles 
One of the groups actually interpreted the picture in the context in which the event really occurred: an x-ray of a truck full of refugees. But they compared it to a local situation. "Paus de arara" are trucks used in the Northeast of Brazil to carry rural workers. They usually lack comfort and, sometimes, even proper transportation conditions. Another group compared the picture to an axé music party, in which a band stands on top of a truck and plays axé music - a kind of Afro-Brazilian musical genre - for the audience below. It is a very common type of party in that region. Therefore, these readings come to show that the way in which people interpret texts is highly influenced by their sociocultural contexts, which involve aspects such as religious affiliation, entertainment situations and social conditions.

It is important to notice that, as stated by Mizan (2014, p. 272), different contexts ascribe different meanings to images. Therefore, reading them as a classroom activity would greatly differ from reading them on a website, in this case a news webpage. Moreover, this first step was dedicated to the visual mode only, so it was not a multimodal analysis.

The second step, then, was to show them the headline (the verbal mode) that accompanied the pictures on the website, making their connection with a piece of news information clearer. After that, I asked the students to resume group discussions. I had prepared a few questions following the four resources model, taking into account both the visual and the verbal modes. This is where the multimodal analysis comes in, since we are now dealing with both modes in conjunction.

The analysis below is based on the questions that I posed for the students, in this second part of the activity, and on their responses. We kept alternating between group discussion and class discussion. For each set of questions/practices, I would give them a certain amount of time for group discussion, followed by class discussion. The first was dedicated to class discussion only.

\subsubsection{Coding practices}

According to Luke and Freebody (1999), the aim of this resource is to "break the code of written texts by recognizing and using fundamental features and architecture." For this activity, I proposed some exercises based on two features in the headline. The first one is the existence of a collective noun ("Mexico police find...") and the subject-verb agreement that it implies. The second feature was the expression "US-bound migrants". 
Most of the students were unfamiliar with this expression, which allowed the exploration of its application in different contexts. For example, the London underground system uses it to show the direction taken by trains: eastbound, northbound, and so on. In Aracaju, and most of Brazil, such a reference is rare, so that other types of reference are used, like city center-suburb, etc.

One of the most difficult practices in language teaching is to treat structural features critically. The above examples were not exactly critical, but what I tried to do was to bring those issues as close as possible to the students' contexts. This is more evident in the second one ("US-bound"), when I took the phrase out of its structure and tried to apply it to the students' lived experiences. Another aspect that could have been explored, still in connection with this phrase, is the fact that it shows to the reader that those migrants were barred still in Mexican soil. The first part of the headline ("Mexico police find") reinforces that idea, giving the police, not the immigrants, the leading role, which could have been avoided by the use of the passive voice ("513 USbound migrants found in trucks by Mexico police"). That could have led to a discussion of how Mexico and the US have probably agreed to fight illegal migration in conjunction, a role that is commonly attributed to US authorities.

The use of the simple present tense ("find") is another common feature in news headlines, and students may find it contradictory to see a present tense applied to a past event. That is not typical of English, but of the genre itself, since it can be found in other languages, including Portuguese. As I mentioned above, this is more in tune with the grammar of the genre than with the grammar of the language.

As far as the analyses of images are concerned, this rationale is also valid. Although I did not ask questions about it, I mentioned to the students that the pictures also have their grammar. This is more evident in the third picture, where the Mexicans can be seen in line after their apprehension. It is a classic journalistic photo, portraying reality with a pretended objectivity. Kress and Van Leeuwen's grammar of visual design (2006, p. 148) can be helpful for deconstructing this idea. First of all, the picture shows the Mexicans looking the other way, thus avoiding the creation of an interaction with the viewer. There is also a certain degree of impersonality that is emphasized by three aspects: the medium shot, the oblique angle and the slightly high angle. First, the medium shot is less personal than the close shot. Second, if the frontal angle denotes involvement, the oblique angle implies detachment. Finally, if the low angle gives power to the represented 
participant, the high angle is a sign of viewer power. All of these aspects show that the pretense objectivity of journalistic photos is in fact a set of choices made by the photographer to create that effect and not as the faithful rendering of reality. The low angle, for example, would have made the Mexicans look more powerful, which was probably not the impression that the photographer intended to create.

\subsubsection{Text meaning practices}

This resource explores the relation between a "text's interior meaning systems" (LUKE; FREEBODY, 1999) and the reader's available knowledge and experiences of other cultural texts and meaning systems. One of the questions posed for this part of the model is: "What are the cultural meanings that can be constructed from these pictures?" (LUKE; FREEBODY apud TEMPLE, 2005, p. 17). Since I wanted the students to talk about their own experiences, especially as related to the topic of migration nowadays, I broke that question down into more specific ones: "Is migration an important topic nowadays? Why (not)?" and "Does it affect you? In what ways?"

For the first question, the students gave some generalized opinions about migration worldwide, US and European immigration laws and drug dealing across borders, especially between Mexico and the US. As for the second question, students brought their opinions closer to their own experience. Starting from an account of how Latin Americans were migrating to Brazil, they went on to mention that these global displacements have had their impact on the local ecology. For the first time they were witnessing the migration to Aracaju, Sergipe's capital city, of people from far away, such as Greeks, Koreans and the Chinese. Furthermore, they commented on a recent shift in migration within Brazil. The classic tendency of people migrating from the North to the South in search of better life conditions seems to be reversing now. One of the students mentioned that in the school where she teaches there are many children from other regions, like São Paulo and Rio Grande do Sul: "It looks like I'm not in Aracaju sometimes," she stated.

\subsubsection{Pragmatic practices}

According to Luke and Freebody (apud TEMPLE, 2005, p. 18), this resource focuses on pragmatic practices by exploring the following questions: "What do I do with this text, here and now? What will others do 
with it? What are my options and alternatives?" For the authors (LUKE; FREEBODY, 1999), the purpose of this resource is "knowing about and acting on the different cultural and social functions that various texts perform inside and outside school". From these guidelines, I proposed the following questions for the students: "Where would you find this kind of picture and headline? Where does the x-ray picture come from? How was it made available to us?"

My intention with these questions was to prompt the students to think about the alleged neutrality of the corporate media, which is supposedly reflected in the language used, both written and visual. Hence, the point was to also question how a news agency had had access to, and had come to hold worldwide publishing rights of, a picture produced by the Mexican local police, which is the case of the x-ray picture (a).

Finally, I wanted them to reflect on how the medium of communication may influence the way in which we make sense of texts, and ultimately of reality itself. This is so because the activity was based on three levels: a) the facts as they had happened; b) the pictures, as they were presented by the media on the Internet; c) the interpretation of the pictures in the classroom, where we were trying to provide the texts with meanings. One thing that nobody took into account when looking at the pictures without the headline was this second level. Everybody was worried about solely finding out what level a) was, i.e. how those images might be related to real events.

\subsubsection{Critical practices}

The aim of this type of practice is to allow learners to "critically analyze and transform texts by acting on knowledge that texts are not ideologically natural or neutral [...] and that their designs and discourses can be critiqued and redesigned in novel and hybrid ways" (LUKE; FREEBODY, 1999). The discussion then revolved around the following questions: "Which positions, voices and interests are at play?" (LUKE; FREEBODY apud TEMPLE, 2005, p. 17), to which I added, "Are there people like you and your friends (or family) in these pictures?"

As a matter of fact, what I intended with the second question was to elicit in the students (pre-service teachers) a reflection about what sort of students they might come to deal with in their future profession. Socially laden topics should be audience sensitive and teachers should take into account - especially in the public sector in Brazil - that their students may 
come from the most diverse backgrounds. Therefore, it would be more advisable if they tried not to have a predetermined class of audience in mind for whom they would ascribe a one-size-fits-all model of behavior, based on commonsensical social values.

In this light, the first question sought to bring to reflection to what extent the immigrants in the pictures were being objectified and simply treated as criminals. We do not have access to their voice, to their version of the situation. In that case, we are stripped of the possibility of learning the possible social, cultural and historical conditions that had prompted those people to act as they did. The next step was to bring the students' attention to the fact that such a situation could also happen to people closer to their reality, people who are treated as criminals and culprits by the media but who do not have the opportunity to give their side of the story. "They are not given a voice," I said. Despite my intention to make students see things from a different perspective, and in connection with local contexts, one of them replied: "If you give them voice, they will take your hands, feet, everything." And added: "For me, they could all rot in jail.".

The idea of "rotting in jail" is very much circulated among TV sensationalist news programs in Brazil, with presenters often supporting tougher police action and stronger criminal laws, such as the death penalty. However, as I mentioned before, teachers-to-be should be aware of the kinds of students that they might come to deal with. This one in particular could come to teach, one day, students who have gone, or are at least close to people who have gone, through such a problem. His reaction is also evidence of how much teachers should be prepared to face the unexpected in their classes (ZACCHI, 2015), especially when dealing with students from different backgrounds. It also shows that sensitive issues should be dealt with carefully in the classroom, but they should not be avoided. Avoiding discussions like this is a way of overlooking the problem and masking prejudices. Finally, bringing controversial issues into the classroom does not necessarily imply a critical approach. The above activity intended to have students reflect on several issues and how their lives might be influenced by them. This can also be done with any text that has a connection to the students' everyday issues.

\footnotetext{
${ }^{5}$ Later, when I mentioned this episode to the in-service teachers, one of them asked: "What's he doing in a teacher education course?"
} 
The four resources model proved to be very useful for the analysis of a multimodal text. I applied the practices following the sequence presented in the model itself, but I would maintain that the sequence of activities can vary according to each classroom context.

\subsection{In-service teachers}

\subsubsection{Interviews}

The data presented in this section were taken from individual, semistructured interviews recorded in audio in 2011 with thirteen teachers from Sergipe who took part in the aforementioned research. Each interview lasted about one hour and sought to collect information about practices and methods in English language teaching in Sergipe. The interviewers were members of the research team and took turns interviewing different teachers.

The activity under analysis here was the final stage of the interview and followed the same steps as the activity in the classroom analyzed above, except for the part based on the four resources model. First, the interviewer only showed the pictures and asked each teacher to interpret the images at will. The teachers were then given the headline, and a brief discussion followed. The interpretations are quite similar to those from the pre-service teachers. Here are some of the interpretations for picture (a):

"These two circles give me the impression that they are on a bus, a moving bus." (Érica) ${ }^{6}$

"Some people partying. On a truck, maybe. Just like people do in the countryside." (Hillary)

"I see something in movement, like sound waves. All I see is a multitude, in movement, but at the same time I think those are fragments, sound frequencies." (Day)

"It looks like radio waves, but it could also be a demonstration, people on strike, calling for their rights. Sometimes it looks like people dancing." (Rejane)

"It seems that there are people standing and people sitting, watching something. Maybe a video or a movie." (pdiamond)

${ }^{6}$ The names of the teachers are fictitious and were chosen by themselves. 
Here again, we can see that the teachers read the images according to their cultural environment, especially when Hillary says that she sees people partying, "just like [they] do in the countryside." On the other hand, these teachers are trying to make sense of a text that does not really make sense to them, so they try to see things there, like people on a bus, dancing or watching a video. The most abstract interpretations come from Day and Rejane, who saw sound or radio waves in the pattern of circles and bars in the first picture. Most of these interpretations would not have been possible if they had known the context - i.e. the headline, the linguistic mode - in advance.

After we showed the headline to them, interesting discussions followed. In relation to the topic about migration, the interviewees mentioned the fact that people from the countryside might move to bigger cities within the state or to other parts of the country, like the Southeast. Whereas Érica stated that students tend to stay in her town and do not want to migrate even to Aracaju (the capital city), for Hillary people tend to leave her town because there are not enough jobs for them.

Another example of how the topic about migration is locally relevant comes from Fatinha, a teacher from Poço Redondo, a town in the Sergipe countryside. In a way, she synthesizes the views of the two teachers above. According to her, people leave her town for big cities, but they are not always successful. Therefore, they usually end up turning to their families to ask for money so that they can afford to go back to their hometown, because "the place where they feel happy is there, in Poço Redondo."

The third image also drew some comments connected to both migration and job seeking. According to some of the interviewees, people (mainly men) leave their towns to look for a temporary job in faraway places, usually in the construction sector. That would have been common practice previous to the 2014 Football World Cup, when there were several construction activities around the country. Another source of jobs could also be found in dam construction sites. Once they arrived at those sites, job seekers, from various parts of the country, would have to wait in lines, as seen in the third picture.

In some interviews, the teachers were also asked about how they would use those images in the classroom. That was done still in the first part of the activity, without the teachers knowing the context of the pictures. They showed some difficulty in devising a way of exploring those images without 
knowing their real purpose. This reaction makes the case for the tendency not to ascribe meaning to images without a verbal support or something that denounces its context of production. During one of the interviews, after I had insisted on the question for a while, calling her attention to the lines and shapes of the images, Day - who was also an undergraduate Dance student - mentioned that she would explore some artistic elements, such as how art presents itself in different ways and how works of art may foster different interpretations and opinions. The divergences between students arising from these perspectives, according to her, could be explored in the classroom. That was probably the closest that any of the participants got to an approach that would not focus on facts, but rely on perception.

\subsubsection{Group discussion}

After all the interviews had been done, the research team and the participants held a meeting to discuss the activity involving the pictures. I also brought to discussion the material that I had prepared for the classroom activity with the undergraduate students. ${ }^{7}$ The objective was not the preparation of classes based on that material, but only discussions about them, which might ultimately provide the teachers with ideas to be developed in class.

Consequently, during the discussion, a few relevant aspects related to the classroom came to the fore. The topic about migration prompted a few comments about discrimination in the classroom, especially in connection with the critical dimension of the model. The teachers talked about a general tendency to label people with their places of origin; for example, addressing them as "Pernambucano" or "Baiano", and not with their real names. Two teachers mentioned that students from rural areas tend to be discriminated, usually resulting in poorer performance in school. According to them, the children of prostitutes are also discriminated and one of the undergraduate students from the research team mentioned that the same happens to the children of convicts and drug addicts.

This subject prompted a very interesting account from Jó, one of the most active teachers in the group. She told us that she had once tried to approach the drug addiction issue, relying only on a written text that she had

${ }^{7}$ This meeting took place on 15 October 2011, in Aracaju. The four resources model had already been introduced to the group in previous meetings. 
brought to the students. To her surprise, one girl student started reporting what she knew about the issue. The student then claimed that she herself was a drug user and that the teacher knew nothing about the subject. After that the student took over and the other students started asking her questions, ignoring the role of the teacher. This episode emphasizes the importance of teachers being open to students' values and backgrounds, avoiding preconceived and prejudiced notions of social groups, as mentioned above in relation to the pre-service teachers. In a way, this was also one of the aims of the activities discussed in this paper, taking into account both the pre-service and the in-service contexts.

During the exploration of the pragmatic practices, another aspect was highlighted. As in the classroom activity developed with the pre-service teachers, the discussion revolved around the way in which the established media outlets portray minority groups. One of the teachers mentioned the case of the Landless Rural Movement (the MST). She said that even those students who are associated with the movement are influenced by the media, and some of them believe that the MST is full of "troublemakers." Another teacher added that most of their colleagues do not see themselves as "workers" and do not identify themselves with a certain struggle for workers' rights, so that they refused to go on a march prepared by both the MST and the teachers union.

As stated above, prior to this discussion the four resources model had already been presented to the group. The reason for that was that most of the in-service teachers were eager to find ways to teach English critically. In Sergipe and most of Brazil, English is still taught in a very structural way, focusing mainly on grammar. And when teachers hear about critique, they usually tend to simply add some sort of discussion to the class, especially about controversial issues. According to the teachers' accounts, whether during the meetings or in their field diaries, the proposal for integrating a critical approach to the teaching of language - or teaching for citizenship, as I had suggested in one of the first meetings - was a very difficult one to put into practice. In a way, most of the teachers could not even conceive of that.

Therefore, one of the aims of the project was to build ways of approaching ELT differently, bringing critique to the classroom and relying on different media and texts, especially multimodal ones. That was the main idea behind joining multimodality and the four resources model. This model allows for the approach to (multimodal) texts from different angles, without 
letting go of the teaching of language items. On two other occasions, before the above discussion, the model had been put into practice, with the teachers preparing materials for the classroom with multimodal texts. The result showed that the integration of multimodality and the four resources model can be quite useful when approaching a text from multiple viewpoints. Although the above discussion did not end with the development of actual activities for the classroom, it gave the teachers ideas on how to explore multimodal texts. As for teaching English critically, and not just "content", Jó wrote the following statement in her field diary, in March 2012, when the project was coming to an end:

I've been learning a new way to deal with language, pedagogy and the world. I can't rely on an education that aims to reproduce contents. I believe that change in education starts in the classroom, when students stop being just receptacles for information and turn into individuals who are able to recreate meanings, so that together we can strive for changes that may positively interfere in their lives.

Being able to "recreate meanings" is not the result of one isolated action, since the project involved several activities and approaches, but the activity with multimodality and making meaning out of images may have had a bearing on such a statement. Furthermore, teacher education, being an ongoing process, presupposes a constant questioning of one's beliefs and practices.

\section{Further considerations}

Despite the ubiquity of visual and multimodal texts in the contemporary world, we are still very much dependent on linguistic texts to make some sense of images. Sometimes, and in some places like art galleries or the classroom, it is not only about making sense of them, but maybe trying to comprehend the "right reading." In a way, this is what happened with the participants in this research when they were faced with visual texts on their own. The first reaction was to look awed and confused, as if they could not make any sense of the pictures. Only after they were prompted to raise their "own" interpretations, did they come up with diverse readings. We still live in a typological society, and schools may be reinforcing that tendency by mostly seeking to legitimize linguistic texts. Yet, as stated by Ferraz (2014, p. 263), based on Freire (2005), the relationship among students and teachers 
is still one that presupposes the transference of knowledge from the latter to the former. Therefore, according to him, reading a picture in class mostly implies students trying to get the possible interpretations expected by the teacher, thus hindering other possibilities of meaning making by students.

To a certain extent, reading images is still a tremendous challenge. One of the purposes of the activities described in this paper was to show students and teachers ways of reading visual and multimodal texts, and using them in the classroom. That might involve varying degrees of imagination, and images offer us a great number of possibilities. According to Kress (2003, p. 4), "Reading the elements of an image 'out of order' is easy or at least possible; it is truly difficult in writing." Ultimately, such a process might contribute to the accomplishment of the aesthetic education put forward by Spivak (2012, p. 122): "training the imagination for epistemological performance" as a resource for knowing the other.

A second aspect worth emphasizing here, and connected only to the visual mode, is that there was a certain variety in the way that the participants read the images, since they were instigated to provide loose interpretations for those images. Even so, a few patterns can be observed due to the fact that the participants share a more or less common cultural background. This is what Anstey and Bull (2006, p. 45) define as literacy identity: somenone's "previous literacy, social, cultural, and technological experiences." For the authors, since this identity is "so influential to meaning making practices, different groups may make different meanings of text because of their different social or cultural backgrounds."

That happens because readers interpret texts very much influenced by the context that surrounds them. However, the second part of the activitymainly with the discussions about migration- also involved the application of "transferred meanings" (KALANTZIS; COPE, 2000, p. 248) to other contexts or cultural sites. This double movement could be seen when the participants were induced to think the local through the global and viceversa. This is especially the case with the text-meaning and critical practices (LUKE; FREEBODY, 1999) explored above.

Thus, global and local migration was an issue that gained considerable attention. Geographical mobility and social inequality are common to social groups worldwide, especially in the Brazilian countryside (ZACCHI, 2015). As a result, global issues can become more meaningful for local teaching/ learning contexts. Images may be a useful means for dealing with such 
issues or, as stated by Dimitriadou, Tamtelen and Tsakou (2011, p. 226), for "gaining access to the cognitive, conceptual and emotional spheres of the 'other'."

However, one should not assume that "strangeness and geographical distance go hand in hand, and works in a binary of strangeness-familiarity when the strange can also be familiar and vice versa", as put forth by Edwards and Usher (2008, p. 40). The authors suggest that "it is rather that the familiar and unfamiliar are reconfigured and reordered and that increased (en)counters with strangeness - direct or indirect - can result in enhanced understanding and sociality as much as increased alienation and/ or hostility." Therefore, promoting discussions about the other does not (and should not) necessarily cause some kind of empathy and identification as a means to eventually erase difference. Rather, this is the moment when difference can be brought to the fore as a powerful signifying resource. Thus, "de-familiarizing the familiar" (SPIVAK, 2012, p. 116) does not imply merely familiarizing the unfamiliar. If on the one hand it is not desirable that social groups remain totally attached to their own values, with no chance for change, on the other hand, simply embracing the other, without critique, will not be enough to cause any kind of transformation.

The importance of a topic such as migration lies in the fact that it refers to the contact between strangers, a process that involves both familiarization and de-familiarization. What is peculiar about Sergipe nowadays is that it is a place where migrants may both go to and come from (and eventually go back to), differently from narratives of other times, which accounted for a place of departure only. Thus, the exploration of migration as a topic was not meant to simply bring a contemporary and sensitive issue to the classroom as a means to foster critical awareness. The idea was to make students and teachers reflect on their contexts in face of a phenomenon that has a global as well as a local reach.

\section{Conclusion}

Overall the reflections raised above aimed to contribute to the teaching of English as a foreign language in Brazil, as regards not only multimodality, but also issues such as migration, local vs. global relationship, cultural differences and interaction in the classroom.

Although it is not possible to ascribe multimodality alone with certain initiatives for change in language teaching, it certainly adds weight 
to the case for transformation. Multimodality is a central mode of meaning making nowadays. As discussed above, the activities developed following multimodality allowed for different ways of reading a text without placing excessive importance on the linguistic mode. They also made way for an enhanced focus on cultural differences. As for the use of images, the transition from a monomodal analysis (the visual mode) to a multimodal one (visual and verbal modes) proved to be quite fruitful, since it made it clear how the different modes intersect and influence each other. If the headline provided some context for the readers, the images provided alternative, different readings, even after the readers were made aware of the context presented by the headline. This is where multimodality shows its specificity: bringing in a different effect not yet available in any of the specific individual modes present in a text (MONTE MOR, 2006, p. 133).

The use of the four resources model also contributed to finding ways of reading the text that connected it to other contexts. As mentioned above, the model was created to encourage different levels of critical literacy which "involves shaping and mastering the repertoire of capabilities called into play when managing texts in ways appropriate to various contexts" (LUKE; FREEBODY, 1999) - and to foster moral, political, social and cultural choices that may ultimately lead to the transformation of reality, for, according to the authors, literacy is not only an aspect of "an individual's history, capability, and possibilities", but also "the collective or joint capabilities of a group, community, or society."

Regarding the subject of migration, the activities allowed for teachers and students to look at local issues with a global perspective, and vice versa. They also provided opportunities to look at differences and similarities when dealing with problems that may have a local as well as a global reach. In this case, difference can be seen as a starting point for the interaction with the other and not as an obstacle to be overcome and eliminated.

\section{References}

ANSTEY, M.; BULL, G. Teaching and learning multiliteracies: changing times, changing literacies. Newark: International Reading Association, 2006.

BARTHES, R. Image, music, text. Translation: Stephen Heath. New York: Hill and Wang, 1977. 
DIMITRIADOU, C.; TAMTELEN, E.; TSAKOU, E. Multimodal texts as instructional tools for intercultural education: a case study. Intercultural Education, Philadelphia, v. 22, n. 2, p. 223-228, 2011.

EDWARDS, R.; USHER, R. Globalisation and pedagogy: Space, place and identity. $2^{\text {nd }} \mathrm{ed}$. New York: Routledge, 2008.

FERRAZ, D.M. Letramento visual: as imagens e as aulas de inglês. In: TAKAKI, N.H.; MACIEL, R.F. (Orgs.). Letramentos em terra de Paulo Freire. Campinas: Pontes, 2014. p. 255-270.

FREIRE, P. Pedagogia do oprimido. $4^{\text {th }}$ ed. Rio de Janeiro: Paz e Terra, 2005.

KALANTZIS, M.; COPE, B. A. Multiliteracies pedagogy: a pedagogical supplement. In: KALANTZIS, M.; COPE, B. (Orgs.). Multiliteracies: Literacy learning and the design of social futures. New York: Routledge, 2000. p. 239-248.

KRESS, G. Multimodality. In: KALANTZIS, M.; COPE, B. (Orgs.). Multiliteracies: Literacy learning and the design of social futures. New York: Routledge, 2000. p. 182-202. KRESS, G. Literacy in the new media age. New York: Routledge, 2003.

KRESS, G.; VAN LEEUWEN, T. Reading images: the grammar of visual design. $2^{\text {nd }}$ ed. New York: Routledge, 2006.

LUKE, A.; FREEBODY, P. Further notes on the four resources model. Reading Online. 1999. Available from: < http://www.readingonline.org/research/ lukefreebody.html>. Access on November 7, 2014.

MIZAN, S. Letramento visual na mídia. In: TAKAKI, N.H.; MACIEL, R.F. (Orgs.). Letramentos em terra de Paulo Freire. Campinas: Pontes, 2014. p. 271-282.

MONTE MOR, W. Reading Dogville in Brazil: Image, language and critical literacy. Language and Intercultural Communication, v. 6 n. 2, p. 124-135, 2006.

MORGAN, B. Revitalising the essay in an English for academic purposes course: critical engagement, multiliteracies and the internet. International Journal of Bilingual Education and Bilingualism, v. 12, n. 3, p. 309-324, 2009.

SILVA, S.B. Letramentos críticos com texto visual - investigando caminhos na formação de professores para a contemporaneidade. In: ZACCHI, V.J.; STELLA, P.R. (Orgs.). Novos letramentos, formação de professores e ensino de língua inglesa. Maceió: Edufal, 2014. p. 161-180.

SNYDER, I. The literacy wars: why teaching children to read and write is a battleground in Australia. Crows Nest: Allen \& Unwin, 2008.

SPIVAK, G.C. An aesthetic education in the era of globalization. Cambridge, Ma: Harvard University Press, 2012.

TEMPLE, C. Critical thinking and critical literacy. Thinking Classroom, v. 6, n. 2, p. 15-20, 2005. 
THE NEW LONDON GROUP. A pedagogy of Multiliteracies designing social futures. In: KALANTZIS, M.; COPE, B. (Orgs.). Multiliteracies: Literacy learning and the design of social futures. New York: Routledge, 2000. p. 9-37.

ZACCHI, V.J. Imagem e movimento: o modo visual na construção da identidade do sem-terra. Revista Brasileira de Linguística Aplicada, Belo Horizonte, v. 9, n. 2, p. 415-439, 2009.

ZACCHI, V.J. Esperando o inesperado: formação de professores numa era de incertezas. In: MOTA, M.B. et alii. (Orgs.). Lingua e literatura na época da tecnologia. Florianópolis: EdUFSC, 2015. p. 261-278.

Data de submissão: 26/12/2015. Data de aprovação: 24/10/2016. 